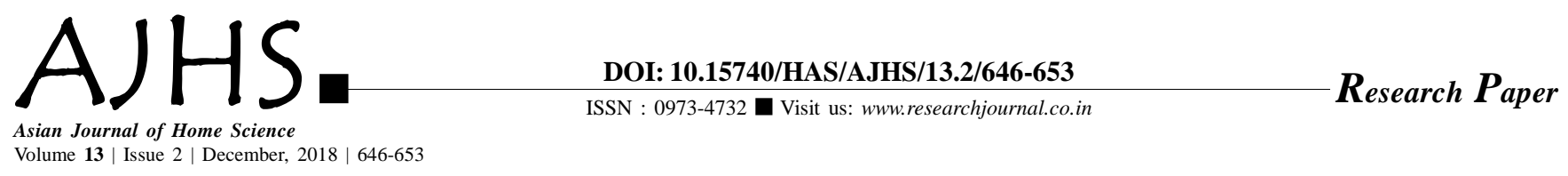

\title{
Intergenerational transition of trousseau practices among women of Malwa region
}

\author{
Manideep Kaur and Harminder Kaur Saini
}

See end of the paper for authors' affiliations

\section{Manideep Kaur}

Department of Apparel and

Textile Science, Punjab

Agricultural University, Ludhiana (Punjab) India

Email : mani_sital@yahoo.co.in
Received: 26.07.2018; Revised: 15.11.2018; Accepted: 28.11.2018

ABSTRACT : This paper examines the extent of bearing clothes, home furnishings, foot wear and handbags in the bridal trousseauamong women of two intergenerational periodsin Malwa region of Punjab. A sample size of 300 respondents was selected which spread over three cities namely Ludhiana, Patiala and Bathinda of Malwa region of Punjab. In the sample, the respondents of the first generation are the mother-in-law, while the respondents of second generation are daughter-in-law. The findings of the study revealed that the quantity of bearing clothes by the brides was found to be increased significantly over the period of time. As against 37.3 per cent of the total respondentsof second generation, only one-fifth of the respondents of first generation were able to maintain more than 31 clothes in bridal trousseau. The quantity of home furnishing, footwear and handbag articles in the bridal trousseau increased significantly over the periods of two generations. As against 40 per cent of the total respondents of second generation, only 19.3 of the respondents of first generation were able to have 11-20 home furnishing articles in bridal trousseau. Similarly, compared to 26.7 per cent of the total respondents of second generation, only 2 per cent of the respondents of first generation were reported to include 11-15 footwear articles in bridal trousseau. The quantity of including handbags in the trousseau has shown significant growth during the study period. Hence, the economic and social transformations in the society lead to increase the bridal articles in the trousseau both in terms of numbers and varieties. The findings of the study could be helpful for the society on account of expanding business opportunities by taking into account the changing trends in fashion and the interest of the young generation with respect to trousseau practices.

KEY WORDS: Intergenerational, Bridal trousseau, Marriages

- HOW TO CITE THIS PAPER : Kaur, Manideep and Saini, Harminder Kaur (2018). Intergenerational transition of trousseau practices among women of Malwa region. Asian J. Home Sci., 13 (2) : 646-653, DOI: 10.15740/HAS/AJHS/13.2/646-653. Copyright@ 2018: Hind Agri-Horticultural Society. 